\title{
Flowers visited by hummingbirds in an urban Cerrado fragment, Mato Grosso do Sul, Brazil
}

\author{
Waldemar Guimarães Barbosa-Filho ${ }^{1,2}$ \& Andréa Cardoso de Araujo ${ }^{1}$ \\ ${ }^{1}$ Laboratório de Ecologia, Centro de Ciências Biológicas e da Saúde, \\ Universidade Federal de Mato Grosso do Sul-UFMS, CP 549, CEP 79070-900, Campo Grande, MS, \\ Brasil. http://www-nt.ufms.br/ \\ ${ }^{2}$ Corresponding author: Waldemar Guimarães Barbosa-Filho,e-mail: waldemargbf@yahoo.com.br
}

\author{
BARBOSA-FILHO, W.G. \& ARAUJO, A.C. Flowers visited by hummingbirds in an urban Cerrado \\ fragment, Mato Grosso do Sul, Brazil. Biota Neotrop. 13(4): http://www.biotaneotropica.org.br/v13n4/en/ \\ abstract?article+bn00213042013
}

\begin{abstract}
Hummingbirds are the main vertebrate pollinators in the Neotropics, but little is known about the interactions between hummingbirds and flowers in areas of Cerrado. This paper aims to describe the interactions between flowering plants (ornithophilous and non-ornithophilous species) and hummingbirds in an urban Cerrado remnant. For this purpose, we investigated which plant species are visited by hummingbirds, which hummingbird species occur in the area, their visiting frequency and behavior, their role as legitimate or illegitimate visitors, as well as the number of agonistic interactions among these visitors. Sampling was conducted throughout 18 months along a track located in an urban fragment of Cerrado vegetation in Campo Grande, Mato Grosso do Sul, Brasil. We found 15 species of plants visited by seven species of hummingbirds. The main habit for ornithophilous species was herbaceous, with the predominance of Bromeliaceae; among non-ornithophilous most species were trees from the families Vochysiaceae and Malvaceae. Hylocharis chrysura was the hummingbird that visited the largest number of plant species and also attended the greater number of agonistic events. The high proportion $(66.7 \%)$ of non-ornithophilous species visited by hummingbirds in the present study was similar to that found in other communities analyzed in Brazil. The fact that ornithophilous species in the area does not offer resources continuously throughout the year should induce hummingbirds to search for alternative resources, and contribute to the high proportion of non-ornithophilous species visited. In general, the floral form was not a barrier to floral visits by hummingbirds, although morphological characteristics of flowers from some plant species may be restrictive. Tabebuia aurea, for example, presents flowers with long corollas, hindering the access to floral resources by the pollinators, what may favor the occurrence of illegitimate visits by hummingbirds. Despite of being a small fragment of Cerrado vegetation, the studied remnant can be considered an important refuge, sheltering a great richness of hummingbird species comparable to several forested areas in Brazil.
\end{abstract}

Keywords: agonistic behavior, fragmentation, ornithophily, pollination.

BARBOSA-FILHO, W.G. \& ARAUJO, A.C. Flores visitadas por beija-flores em um fragmento urbano de Cerrado, Mato Grosso do Sul, Brasil. Biota Neotrop. 13(4): http://www.biotaneotropica.org.br/v13n4/pt/ abstract?article+bn00213042013

Resumo: Os beija-flores são os principais vertebrados polinizadores na região Neotropical, mas pouco ainda se conhece sobre as interações entre beija-flores e flores em áreas de Cerrado. O objetivo deste estudo foi descrever as interações entre espécies de plantas em floração (ornitófilas e não-ornitófilas) e beija-flores, em um fragmento urbano de Cerrado. Para isso, investigamos quais espécies de plantas são visitadas por beija-flores, quais espécies de beija-flores ocorrem na área, seu comportamento e frequência de visitas, sua atuação como visitante legítimo ou ilegítimo, assim como o número de interações agonísticas entre essas aves. Foram realizados 18 meses de amostragem ao longo de uma trilha localizada em um fragmento urbano de Cerrado em Campo Grande, Mato Grosso do Sul, Brasil. Foram encontradas 15 espécies de plantas visitadas por sete espécies de beija-flores. O principal hábito para as espécies ornitófilas foi herbáceo, com a predominância da família Bromeliaceae; entre as não-ornitófilas o principal hábito foi o arbóreo, com a predominância das famílias Vochysiaceae e Malvaceae. Hylocharis chrysura foi o beija-flor que realizou o maior número de visitas às flores e o que participou de maior número de ocorrências agonísticas. A elevada proporção $(66,7 \%)$ de espécies não-ornitófilas visitadas por beijaflores no presente estudo também vem sendo reportada em outras comunidades analisadas no Brasil. O fato de as espécies ornitófilas da área estudada não oferecerem recurso de forma contínua ao longo de todo o ano deve induzir os beija-flores a procurar recursos alternativos, e contribuir para a alta proporção de espécies não-ornitófilas visitadas. De modo geral, a forma floral não foi obstáculo às visitas dos beija-flores, apesar de as características morfológicas de algumas espécies de plantas poderem ser restritivas. Tabebuia aurea, por exemplo, tem flores de corola longa, o que dificulta o acesso ao néctar pelos beija-flores, podendo favorecer a ocorrência de visitas ilegítimas. Apesar de ser um fragmento de Cerrado pequeno, o remanescente estudado pode ser considerado um importante refúgio, abrigando riqueza de espécies de beija-flores comparável à de diversas formações florestais do Brasil.

Palavras-chave: comportamento agonístico, fragmentação, ornitofilia, polinização. 


\section{Introduction}

The Cerrado encompasses $2.000 .000 \mathrm{Km}^{2}$, being the second largest Brazilian ecosystem in extent; it occurs mainly in the central region of Brazil and occupies $21 \%$ of the country (Klink \& Machado 2005). Despite of being one of the 25 hotspots for conservation (Myers et al. 2000), more than 55\% of the Cerrado has been transformed or degraded by human activities (Machado et al. 2004), and its destruction continues in an accelerated rate.

Forest fragmentation compromises the biological diversity due to variations in the availability of resources and conditions. It affects species differently, according to their habitat requirements (Fahrig et al. 2011). Despite of the relatively high amount of data on hummingbird assemblages, knowledge about inter and intra-specific interactions, and their relationships with plants in Cerrado vegetation is still poorly known (Araújo 2010, Araújo et al. 2011, Maruyama 2011, Machado 2012), being these information even scarcer for urban remnants (Mendonça \& Anjos 2005). We found only one study regarding these interactions for urban fragments of Cerrado vegetation (Rodrigues \& Araujo 2011).

Currently, hummingbirds (Trochilidae) occur only in the American continent and comprise one of the largest families of birds, including 328 species, among which, 83 species occur in Brazil according to Brazilian Ornithological Records Committee - CBRO (Comitê... 2013). Furthermore, these birds are the main vertebrate pollinators, acting as pollinators of up to $22 \%$ of neotropical angiosperm species (Rocca \& Sazima 2010).

Some characteristics in angiosperm flowers, such as bright colors (especially red), abundant nectar, odorlessness, tubular corollas and nectary away from the stigma and anthers, are related to hummingbird pollination (Faegri \& van der Pijl 1979, Endress 1994). However, several studies have shown that these birds often include variable percentages (32\% to $71 \%$ ) of species with diverse floral characteristics, not related with ornithophily, in their diet (Dalsgaard et al. 2008, Rocca \& Sazima 2010). Additionally, some ornithophilous species present floral characteristics, like corolla length, that may also exclude some visitors (Endress 1994), forcing short-billed hummingbirds to search for different resources.

This paper aims to describe the interaction between flowering plants (ornithophilous and non-ornithophilous species) and hummingbirds in an urban Cerrado remnant. For this purpose, we investigated which plant species are pollinated by hummingbirds, which hummingbird species occur in the area, their visiting frequency and behavior, their role as legitimate or illegitimate visitors; as well as the number of agonistic interactions recorded among these birds.

\section{Material and Methods}

This study was conducted in a Cerrado fragment in the Private Reserve of Natural Heritage belonging to the Federal University of Mato Grosso do Sul (RPPN/UFMS) in Campo Grande (20 $27^{\prime} \mathrm{S}$, $54^{\circ} 37^{\prime} \mathrm{W}$ ). The area is approximately $360.500 \mathrm{~m}^{2}$ and is composed mainly by cerrado sensu stricto and dense woodland vegetation (Oliveira \& Sigrist 2008). The climate is the Rainy Tropical Savannah type (subtype Aw, Köppen 1948) with two well-defined seasons, a dry and cold one, from May to September, and another hot and rainy season, from October to April. The average annual rainfall is $1532 \mathrm{~mm}$, the relative humidity is generally low, rarely reaching $80 \%$, and average annual temperatures ranges between 20 and $22^{\circ} \mathrm{C}$, with an average maximum temperature of $29.4^{\circ} \mathrm{C}$ and minimum of $17.4^{\circ} \mathrm{C}$ (Monitoring Center of Weather, Climate and Water of Mato Grosso do Sul) (Centro... 2013).

Data was collected during 18 months (June 2006 to November 2007) along a $1500 \mathrm{~m}$ long and $6 \mathrm{~m}$ wide track, totaling $9000 \mathrm{~m}^{2}$ of sampling area. Flowers were classified as ornithophilous or nonornithophilous, according to attributes described for ornithophily (Machado \& Rocca 2010). For all species whose flowers were visited by hummingbirds, data on the habit and number of opened flowers per day were recorded. Species were identified in the field or with the help of experts. All species of plants were deposited at the Herbarium of Federal University of Mato Grosso do Sul (CGMS). Plant nomenclature followed the Angiosperm Phylogeny Group (APG III, Mark et al. 2009).

Focal observations were conducted at different times throughout the day, even during the hottest hours, from sunrise to sunset, and each observation session lasted $90-240 \mathrm{~min}$. Hummingbirds were identified using a field guide (Grantsau 1988). Nomenclature of hummingbirds followed the proposed by Brazilian Ornithological Records Committee - CBRO (Comitê... 2013). Species of hummingbirds with evident sexual dimorphism were treated separately.

In each session of focal observation it was recorded the number of flowers available, the species of hummingbird visitors, the timing of visits and the number of flowers visited. Visits were classified as legitimate (if hummingbirds contacted anthers and/or stigma of the flower) or illegitimate (if hummingbirds did not contact the reproductive structures of the flower) (Faria \& Araujo 2010). Visiting behavior of hummingbirds and all occurrences of intra or interspecific agonisms (i.e. when the hummingbirds fight each other), were recorded during focal observations in plant species.

The Mann-Whitney test was used to calculate if the frequency of visits by hummingbirds (number of flowers visited/ number of flowers observed /minute) differed among ornithophilous and nonornithophilous species and to test if the visiting rates of hummingbirds (number of visits/minute) differed between these two types of flowers. The Spearman's correlation was performed to verify if the rate of visits varies with the total number of open flowers per individual.

\section{Results}

It was recorded visits by hummingbirds in 15 species of plants, being five ornithophilous (33.3\%) and 10 non-ornithophilous $(66,6 \%)$ species. Among ornithophilous species, Bromeliaceae was the family with more species visited by hummingbirds, and among non-ornithophilous Vochysiaceae and Malvaceae were the families with more species visited by these birds (Table 1). Among the ornithophilous species recorded, four are herbs and one is a liana (Table 1). Most of the non-ornithophilous species visited by hummingbirds are trees (seven species), and the remaining three species are a shrub, a subshrub and a liana (Table 1). Most ornithophilous species presents open (46.6\%), tubular (40\%), brush or gullet $(6.7 \%)$ corolla types. Corolla color was mainly red $(60 \%)$, followed by lilac $(20 \%)$ or orange $(20 \%)$. Among non-ornithophilous species, most presented open flowers $(70 \%)$, followed by gullet, brush and tubular types (10\% each), with white (40\%), yellow (30\%), lilac $(20 \%)$ or purple $(10 \%)$ corollas (Table 1$)$. The majority of the non-ornithophilous species flowered in the dry season, while most ornithophilous flourishes in the rainy one (Table 2). The average number of open flowers per individual per day was $\bar{x}=4.62 \pm 3.81$ $(\mathrm{n}=48)$ on ornithophilous, and $\overline{\mathrm{x}}=154.92 \pm 319.99(\mathrm{n}=174)$ on non-ornithophilous species.

Seven species of hummingbirds belonging to the subfamily Trochilinae were recorded: Anthracothorax nigricollis (Vieillot, 1817), Chlorostilbon lucidus (Shaw, 1812), Eupetomena macroura (Gmelin, 1788), Heliomaster squamosus (Temminck, 1823), Hylocharis chrysura (Shaw, 1812), Thalurania furcata (Gmelin, 1788) and Amazilia fimbriata (Gmelin, 1788). The greater richness 
Table 1. Characteristics of habit, shape and corolla color, as well as mean number ( \pm standard deviation) of open flowers per individual per day of ornithophilous (underlined) and non-ornithophilous species visited by hummingbirds in the Private Reserve of Natural Heritage (RPPN) belonging to the Federal University of Mato Grosso do Sul (UFMS).

\begin{tabular}{|c|c|c|c|c|}
\hline Families and plant species & habit & corolla shape & corolla color & $\mathbf{n}^{\circ}$ flowers/ individual/day \\
\hline \multicolumn{5}{|l|}{ Bromeliaceae } \\
\hline Ananas ananassoides (Baker) L. B. Sm. & herb & tubular & lilac & $4.6 \pm 3.0(21)$ \\
\hline Bromelia balansae Mez & herb & tubular & red & $9.4 \pm 5.6(8)$ \\
\hline Bromelia plumieri (E. Morren) L.B. Sm. & herb & tubular & red & $6.0 \pm 3.5(9)$ \\
\hline Dyckia leptostachya Baker & herb & tubular & orange & $4.0 \pm 2.6(4)$ \\
\hline \multicolumn{5}{|l|}{ Bignoniaceae } \\
\hline Tabebuia aurea (Silva Manso) Benth. \& Hook. f. ex Moore & tree & gullet & yellow & $149.2 \pm 139.6(12)$ \\
\hline \multicolumn{5}{|l|}{ Fabaceae } \\
\hline Camptosema ellipticum (Desv.) Burk & liana & tubular & red & $1.4 \pm 1.1(6)$ \\
\hline Bauhinia ungulata $\mathrm{L}$. & shrub & brush & white & $2.9 \pm 3.5(16)$ \\
\hline \multicolumn{5}{|l|}{ Malvaceae } \\
\hline Eriotheca pubescens (Mart. \& Zucc.) Schott \& Endl. & tree & open & white & $12.5 \pm 3.5(2)$ \\
\hline Luehea paniculata Mart. & tree & open & white & $18.7 \pm 17.9(20)$ \\
\hline \multicolumn{5}{|l|}{ Sapindaceae } \\
\hline Serjania ovalifolia Radlk. & liana & open & white & $3.5 \pm 2.1(21)$ \\
\hline \multicolumn{5}{|l|}{ Simaroubaceae } \\
\hline Simarouba versicolor A. St. Hil. & tree & open & purple & $219.3 \pm 254.1(15)$ \\
\hline \multicolumn{5}{|l|}{ Styracaceae } \\
\hline Styrax ferrugineus Nees \& Mart. & tree & open & yellow & $25.0 \pm 11.2(5)$ \\
\hline \multicolumn{5}{|l|}{ Verbenaceae } \\
\hline Verbena hirta Spreng. & subshrub & tubular & lilac & $240.4 \pm 400.6(10)$ \\
\hline \multicolumn{5}{|l|}{ Vochysiaceae } \\
\hline Qualea parviflora Mart. & tree & open & lilac & $108.8 \pm 95.2(23)$ \\
\hline Vochysia cinnamomea Pohl & tree & open & yellow & $270.1 \pm 523.7(36)$ \\
\hline
\end{tabular}

Values in parentheses represent the number of sampled individuals.

Table 2. Flowering time and flower visitors of 15 plant species (ornithophilous underlined) visited by hummingbirds in the RPPN/UFMS. Underlined months represent hot and rainy season. Lines correspond to flowering recorded in the area and numbers correspond to the species of hummingbirds recorded in each sampled month: 1 = Hylocharis chrysura, $2=$ Eupetomena macroura, $3=$ Chlorostilbon lucidus female, $4=$ Heliomaster squamosus, $5=$ Chlorostilbon lucidus male, $6=$ Thalurania furcata female, $7=$ Thalurania furcata male, $8=$ Anthracothorax nigricollis female, $9=$ Anthracothorax nigricollis male, $10=$ Amazilia fimbriata.

\begin{tabular}{|c|c|c|c|c|c|c|c|c|c|c|c|c|c|c|c|c|c|c|}
\hline & \multicolumn{7}{|c|}{2006} & \multicolumn{11}{|c|}{2007} \\
\hline & June & July & Aug. & Sept. & Oct. & Nov. & Dec. & Jan. & Feb. & Mar. & Apr. & May & June & July & Aug. & Sept. & Oct. & Nov. \\
\hline Bromelia plumieri & & & & & & & 1 & & & & & & & & & & & \\
\hline Tabebuia aurea & & 2 & & & & & & & & & & & & & 4 & & & \\
\hline Serjania ovalifolia & & & & 3,5 & & & & & & & & & & & 3 & & & \\
\hline Ananas ananassoides & & & & $1,3,5$ & & & & & & & & & & & & 1,3 & & \\
\hline Verbena hirta & & & & 1,3 & & & & & & & & & & & & & & 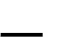 \\
\hline Bromelia balansae & & & & & 1.2 .3 .56 .78 & & & & & & & & 1,2 & & & & & \\
\hline Bauhinia ungulata & & & 3 & & & & & & & $\overline{5}$ & & & & & & & & \\
\hline Camptosema ellipticum & & & & & & & & & & & & & & & 3 & & & \\
\hline Vochysia cinnamomea & & & & & & & & & $1,2,3,8$ & $\begin{array}{ll}10 & 1,2,9,10 \\
\end{array}$ & & & & & & & & \\
\hline Simarouba versicolor & & & & & & & & & & & $1,2,3$ & & & & & & & \\
\hline Styrax ferrugineus & & & & & & & & & & & & & 1,5 & & & & & \\
\hline Eriotheca pubescens & & & & & & & & & & & & & & & & 1,2 & & \\
\hline Luehea paniculata & & & & & & & & & & & & & & & 3,5 & & & \\
\hline Qualea parviflora & & & & & & & & & & & & & & & & & & 1 \\
\hline Dyckia leptostachya & & & & & & & & & & & & & & & & & & 1 \\
\hline
\end{tabular}


of hummingbirds' species $(\mathrm{n}=5)$ was recorded in October 2006, during the rainy season (Table 2). But between November 2006 and January 2007 there was no record of hummingbirds visiting plants. Hylocharis chrysura was the hummingbird species that remained in the area for the longer period of time, being recorded in nine months, while $H$. squamosus, males of $A$. nigricollis and males and females of T. furcata were recorded only in one month (Table 2).

The frequency of visits of hummingbirds did not vary significantly between ornithophilous and non-ornithophilous flowers $(\mathrm{U}=27.5$, $\mathrm{p}=0.6152)$. The ornithophilous species Bromelia balansae presented the highest frequency of visits $(\mathrm{x}=0.0174 \pm 0.0252$, $\mathrm{n}=20$ ) and, among the non-ornithophilous, Simarouba versicolor $(\mathrm{x}=0.0397 \pm 0.0271, \mathrm{n}=5)$ was the most visited species. The visiting rates did not vary with the number of open flowers, although it presented a marginally significant level $(\mathrm{r}=0.4987, \mathrm{p}=0.0585$, $\mathrm{n}=15)$. Rate of visits also did not differ $(\mathrm{U}=31.5 ; \mathrm{p}=0.92)$ between types of flowers (ornithophilous or non-ornithophilous).

All plant species recorded at RPPN/UFMS received legitimate visits by hummingbirds. However, the proportion of legitimate visits differed between ornithophilous and non-ornithophilous species. While among the ornithophilous all visits were legitimate, amongst non-ornithophilous species some visits (30\%) were illegitimate. Only Eriotheca pubescens received equal proportions (1:1) of legitimate and illegitimate visits, considering visits of all hummingbirds together.

Visiting behavior of hummingbirds varied among plant species. In Bromelia balansae, Hylocharis chrysura visited all flowers from a group of individuals and then leaved the clump, returning again after a period ranging from a few minutes up to 40 minutes. In Vochysia cinnamomea this hummingbird visited flowers of some individuals in a sequence and then perched nearby (for 1 to 35 minutes) before restarting the visits. In the plants species Ananas ananassoides, Serjania ovalifolia, Simarouba versicolor, Styrax ferrugineus and Dyckia leptostachya, the hummingbird $H$. chrysura visited the flowers (with intervals ranging from 1 to 90 minutes) and then leaved the site.

Thalurania furcata females visited flowers of all individuals in the clump of $B$. balansae at intervals ranging from 1 to 16 minutes and then perched nearby, attacking whenever another hummingbird approached to the clumps. In most of the plant species, E. macroura visited the flowers with longer intervals and showed no agonistic behavior. This species visited flowers and perched in individuals of Vochysia cinnamomea, often displacing other hummingbirds that were approaching the flowers during the intervals between visits. Flowers of Bromelia plumieri, Verbena hirta, Eriotheca. pubescens, Luehea paniculata, Camptosema ellipticum, Bauhinia ungulata e Qualea parviflora seem to have little importance as resources for hummingbirds in the area because they were only occasionally visited by hummingbirds, with low frequencies and rates of visits (Table 3 ).

During visits to the flowers, the largest number of agonistic interactions was recorded between two individuals of $H$. chrysura, followed by interactions between $H$. chrysura and females of $C$. lucidus. On the other hand, males of A. nigricollis and females of $T$. furcata were not displaced in any interaction. There was no record of agonistic interactions involving neither H. squamosus nor males of T. furcata (Table 4).

\section{Discussion}

The high proportion of non-ornithophilous species visited by hummingbirds in this study has already been reported for other communities and attributed to several factors. For natural fragments of vegetation ("capões") in southern Pantanal, Mato Grosso do Sul, Brazil, it was suggested that the scarcity of ornithophilous species in the area can explain this (Araujo \& Sazima 2003). In a dry forest in Mexico this high proportion is argued to be related to the dominance of ornithophilous species by territorial hummingbirds (Arizmendi \& Ornelas 1990). In addition, this great proportion of visits to nonornithophilous flowers is attributed to the high abundance of this kind of flowers, which provide nectar with energy values similar to those from ornithophilous species (Nicolson \& Thornburg 2007). In the RPPN/UFMS, this can be justified by the fact that ornithophilous species do not offer resources continuously throughout the year, which should induce hummingbirds to look for non-ornithophilous species in some periods of the year, as already proposed for hummingbirdflower communities in Chapada Diamantina (Machado et al. 2007, Machado 2009).

Table 3. Plant species, total time of focal observations, hummingbird visitors, frequency (number of flowers visited/total number of observed flowers/minute) and visiting rate (number of visits/minute) to flowers in Private Reserve of Natural Heritage (RPPN) belonging to the Federal University of Mato Grosso do $\mathrm{Sul}$ (UFMS). An = Anthracothorax nigricollis, $\mathrm{Cl}=$ Chlorostilbon lucidus, $\mathrm{Em}=$ Eupetomena macroura, $\mathrm{Hc}=$ Hylocharis chrysura, $\mathrm{Tf}=$ Thalurania furcata, $\mathrm{Hs}=$ Heliomaster squamosus, $\mathrm{Af}=$ Amazilia fimbriata $(\widehat{\partial}=$ male or $+=$ female $)$.

\begin{tabular}{|c|c|c|c|c|}
\hline Species & Total focal time (min) & Hummingbird visitors & Frequency * 100 & Rate *100 \\
\hline Ananas ananassoides & 1658 & $\mathrm{Hc}, \mathrm{Cl}+, \mathrm{Cl}^{\curvearrowright}$ & $39.0 \pm 1.3(15)$ & 22.8 \\
\hline Bromelia balansae & 1198 & $\mathrm{Hc}, \mathrm{Cl} \uparrow, \mathrm{Cl}^{\lambda}, \mathrm{Em}, \mathrm{Tf} \uparrow, \mathrm{Tf}^{\lambda}, \mathrm{An}_{+}$ & $1.7 \pm 2.5(20)$ & 176 \\
\hline Bromelia plumieri & 120 & $\mathrm{Hc}$ & $0.2 \pm 0.0(1)$ & 2.7 \\
\hline Dyckia leptostachya & 406 & $\mathrm{Hc}$ & $0.3 \pm 0.1(3)$ & 3.0 \\
\hline Camptosema ellipticum & 90 & $\mathrm{Cl}+$ & $0.5 \pm 0.0(1)$ & 5.0 \\
\hline Tabebuia aurea & 878 & $\mathrm{Cl} \widehat{\jmath}, \mathrm{Em}, \mathrm{Hs}$ & $0.1 \pm 0.2(0)$ & 1.9 \\
\hline Bauhinia ungulata & 719 & $\mathrm{Hc}, \mathrm{Cl}+$, $\mathrm{Em}$ & $1.4 \pm 2.0(2)$ & 4.3 \\
\hline Serjania ovalifolia & 617 & 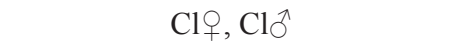 & $0.3 \pm 0.5(6)$ & 18.6 \\
\hline Simarouba versicolor & 246 & $\mathrm{Hc}, \mathrm{Cl}+$ & $4.0 \pm 2.7(5)$ & 48.0 \\
\hline Styrax ferrugineus & 530 & $\mathrm{Hc}, \mathrm{Cl} \widehat{\circ}$ & $2.0 \pm 2.5(5)$ & 73.0 \\
\hline Verbena hirta & 180 & $\mathrm{Hc}, \mathrm{Cl}+$ & $0.1 \pm 0.0(1)$ & 19.4 \\
\hline Vochysia cinnamomea & 220 & $\mathrm{Hc}, \mathrm{Cl}_{+}, \mathrm{Em}, \mathrm{Af} ., \mathrm{Na}_{+}, \mathrm{An}^{\widehat{ }}$ & $0.4 \pm 0.7(20)$ & 614.0 \\
\hline Qualea parviflora & 240 & $\mathrm{Hc}$ & $0.1 \pm 0.0(1)$ & 12.0 \\
\hline Luehea paniculata & 175 & $\mathrm{Cl}+\mathrm{Cl}^{\top}{ }^{-}$ & $0.1 \pm 0.1(2)$ & 3.0 \\
\hline Eriotheca pubescens & 365 & $\mathrm{Hc}, \mathrm{Em}$ & $2.9 \pm 3.0(6)$ & 53.0 \\
\hline
\end{tabular}

Values in parentheses represent the number of sampled individuals 
Table 4. Matrix of agonistic interactions recorded for seven species of hummingbirds that visited flowers in the Private Reserve of Natural Heritage (RPPN) belonging to the Federal University of Mato Grosso do Sul (UFMS). Species on lines are the dominant in the interactions and species in columns correspond to the subordinate ones. For each species it was calculated the sum of the horizontal (number of times the specie displaced another one) and the vertical (number of times that the species has been displaced) axes. $\mathrm{An}=$ Anthracothorax nigricollis, $\mathrm{Cl}=$ Chlorostilbon lucidus, Em $=$ Eupetomena macroura, $\mathrm{Hc}=$ Hylocharis chrysura, $\mathrm{Tf}=$ Thalurania furcata, $\mathrm{Af}=$ Amazilia fimbriata $(\hat{O}=$ male or $\phi=$ female $)$.

\begin{tabular}{|c|c|c|c|c|c|c|c|c|c|}
\hline & Hc & $\mathbf{C l} \mathbf{O}^{\wedge}$ & $\mathbf{C l} q$ & $\mathbf{E m}$ & $\operatorname{An}+$ & $\mathbf{A n}^{\lambda}$ & Tff & Af & $\Sigma_{1}$ \\
\hline $\mathrm{Hc}$ & 27 & 1 & 16 & & & & & & 44 \\
\hline $\mathrm{Cl}^{\lambda}$ & 1 & & & & & & & & 1 \\
\hline $\mathrm{Cl}$ 우 & 10 & & & & & & & & 10 \\
\hline $\mathrm{Em}$ & 4 & & & 1 & 8 & & & & 13 \\
\hline $\mathrm{An}_{+}$ & 3 & & & 1 & & & & 2 & 6 \\
\hline $\operatorname{An}{ }^{\lambda}$ & 2 & & 1 & & & & & & 3 \\
\hline Tf우 & & & 2 & & & & & & 2 \\
\hline Af & & & & & & & & & 0 \\
\hline$\Sigma_{2}$ & 47 & 1 & 19 & 2 & 8 & 0 & 0 & 2 & 79 \\
\hline
\end{tabular}

Most species visited by hummingbirds were trees, and this habit was represented only by non-ornithophilous species in this study. Similar findings were already reported for an urban area in southern Brazil (Mendonça \& Anjos 2005). Among ornithophilous species, herbaceous was the most representative life form, which is related to the prevalence of Bromeliaceae species in the present study. The prevalence of Bromeliaceae for ornithophilous species visited by hummingbirds suggests the high importance of this family as resource for hummingbirds in RPPN/UFMS, which has been already reported by some authors (e.g. Buzato et al. 2000, Piacentini \& Varassin 2007), especially in more humid areas like the Atlantic forest. Regardless of such outcomes, it is not possible to conclude that Bromeliaceae is also the most important ornithophilous family in Cerrado vegetation, since the studied area is a quite small and isolated fragment. Moreover, in other studies conducted in this environment (e.g. Rodrigues \& Araujo 2011, Maruyama 2011) there was no predominance of any plant family visited by hummingbirds.

Flowering period of most species visited by hummingbirds was concentrated at the end of the dry season, similar to that reported in other studies (Arizmendi \& Ornelas 1990, Araujo \& Sazima 2003). However, flowering periods of ornithophilous species were concentrated in the rainy season, which coincides with the period that more species of hummingbirds were recorded at RPPN/UFMS. This pattern could indicate the occurrence of seasonal populational movements to areas with greater availability of food resources (Machado et al. 2007).

The number of hummingbird species recorded in RPPN/UFMS is comparable to the reported in well-preserved forested areas (e.g. Lara 2006, Faria \& Araujo 2010, Ortiz-Pulido et al. 2012). This suggests that small forest fragments may play important role as refuge sites for hummingbird species that occur in urban areas (Rodrigues \& Araujo 2011). Also, in a landscape scale, these fragments may act as "stepping stones" for some hummingbird species (Metzger 2001). Some bird species are able of long distance flights, crossing open areas, as cities or cultivated fields, and using resources distributed in different forest fragments (Hadley \& Betts 2009).

The similarity in the number of available flowers, as well as in the rate and frequency of visits of hummingbirds on ornithophilous and non-ornithophilous flowers, suggests that the choice of flowers by these birds may depend more on other variables (e.g. quantity and quality of nectar, availability of flowers) than its pollination syndrome. Factors such as the amount of nectar obtained at the last visited flower, the competition between visitors and the spatial distribution of flowers may be important in explaining the frequency of visits by hummingbirds (Sulikowski \& Burke 2010).
The occurrence of legitimate visits in all plant species indicates that the hummingbirds are potential pollinators of this plant community, although most species visited by them did not present the specified characteristics of ornithophilly (Faegri \& van der Pijl 1979). However, in some non-ornithophilous species, hummingbirds could act as secondary pollinators, since in variable proportions of visits they did not contact the reproductive structures of flowers, acting as illegitimate visitors (Oliveira \& Gibbs 2000). Effectiveness of hummingbirds as pollinators of this "non-ornithophilous" group still must be evaluated. Several studies have not found a clear pattern linking groups of pollinators and the colors of visited flowers (Altshule 2003). The high number of white flowers visited by hummingbirds in this study corroborates other studies that have reported the white color as the second most frequent floral color from plants pollinated by hummingbirds. (Lunau et al. 2011). Moreover, in general, floral morphology is not an obstacle for hummingbird visitation, although some morphological characteristics of flowers proved to be restrictive as, for example, in the interactions between short-billed hummingbirds and flowers with long corollas (Dalsgaard et al. 2009).

In the studied fragment, the recorded Trochilinae acted also as trapliners (sensu Feinsinger \& Colwell 1978), regularly moving between clumps of resources. It is not common because hummingbirds of this subfamily tend to be territorial and generalists in the use of floral resources, while traplining tend to be a behavior most frequent to hummingbirds in Phaethornithinae subfamily (Machado et al. 2007). However, aggressive and territorial behavior in Phaethornithinae have also been reported in some studies (e.g. Sazima et al. 1995, Rocca \& Sazima 2008).

It was not possible to relate the effect of spatial and temporal differentiation of resource use among hummingbirds in this study. However, the high frequency of agonistic encounters recorded in the study area may be due to a possible lack of vertical stratification, as well as overlapping periods of foraging among different species of hummingbirds (Mitchell et al. 2009).

The dominance of certain species of hummingbirds in agonistic interactions often has been related to their body size (Antunes 2003). Our data support this idea since the largest species found ( $E$. macroura) was dominant over the smaller ones. However, most of the recorded agonistic interactions occurred between species smaller than E. macroura, and were intra (e.g. H. chrysura) and interspecific (e.g. H. chrysura $\mathrm{x}$ C. lucidus). Smaller and hierarchically subordinated hummingbirds may use flowers located on the peripheries of large clumps defended by dominant hummingbirds, acting as territory parasites (Feinsinger \& Colwell 1978). This differentiation in the use of resources among hummingbirds of different sizes may favor 
a higher frequency of agonistic behavior among smaller species (Feinsinger \& Colwell 1978). Thus, smaller hummingbirds tend to compete only among themselves for accessing resources that are not used by larger species (Cotton 1998).

Despite its small size, the RPPN/UFMS may be regarded as an important refuge for hummingbird species, harboring a richness of species comparable to that found in well-preserved areas of different forested formations of Brazil (e.g. Araujo \& Sazima 2003, Machado et al. 2007). Also, hummingbirds recorded in RPPN/ UFMS are potentially important pollinators of ornithophilous and non-ornithophilous species that occur within the area, being frequent visitors of these species. The supply of flowers throughout the year indicates that RPPN/UFMS can maintain individuals of hummingbirds permanently, thus underscoring the importance of this forest fragment for these birds.

\section{Acknowledgements}

For CNPq (Conselho Nacional de Desenvolvimento Cientifico e Tecnológico) for the Scientific Initiation Scholarship for the first author, and Dr. Arnildo Pott for the identification of plant species.

\section{References}

ALTSHULE, D.L. 2003. Flower color, hummingbird pollination, and habitat irradiance in four Neotropical Forests. Biotropica 35(3):344-355.

ANTUNES, A.Z. 2003. Partilha de néctar de Eucalyptus spp., territorialidade e hierarquia de dominância em beija-flores(Aves: Trochilidae) no sudeste do Brasil. Ararajuba 11(1):39-44.

ARAUJO, A.C. \& SAZIMA, M. 2003. The assemblage of flowers visited by hummingbirds in the "capões" of southern Pantanal, Mato Grosso do Sul, Brazil. Flora 198(6):427-435. http://dx.doi.org/10.1078/0367-2530-00116

ARAÚJO, F.P. 2010. A comunidade de plantas utilizadas e suas interações com beija- flores em uma área de Cerrado, Uberlândia - Minas Gerais. Tese de Doutorado, Universidade Estadual de Campinas.

ARAÚJO, F.P., BARBOSA, A.A.A. \& OLIVEIRA, P.E. 2011. Floral resources and hummingbirds on an island of flooded forest in Central Brazil. Flora 206:827-835. http://dx.doi.org/10.1016/j.flora.2011.04.001

ARIZMENDI, M.C. \& ORNELAS, J.F. 1990. Hummingbirds and their floral resources in a tropical dry forest in Mexico. Biotropica 22(2):172-180. http://dx.doi.org/10.2307/2388410 http://dx.doi.org/10.2307/2388410

BUZATO, S., SAZIMA, M. \& SAZIMA, I. 2000. Hummingbird-pollinated floras at three Atlantic forest sites. Biotropica 32(4b):824-841. http:// dx.doi.org/10.1111/j.1744-7429.2000.tb00621.x

CENTRO DE MONITORAMENTO DE TEMPO, DO CLIMA E DOS RECURSOS HÍDRICOS DE MATO GROSSO DO SUL - CEMTEC. 2013. http://www.agraer.ms.gov.br/cemtec (último acesso em 15/01/2013).

COMITÊ BRASILEIRO DE REGISTROS ORNITOLÓGICOS - CBRO 2013. Lista das aves do Brasil. http://www.cbro.org.br (último acesso em 15/01/2013).

COTTON, P.A. 1998. The community organization of a lowland Amazonian forest. Ibis $140(2): 512-521$.

DALSGAARD, B., GONZALEZ, A.M.M., OLESEN, J.M., OLLERTON, J., TIMMERMANN, A., ANDERSEN, L.H. \& TOSSAS, A.G. 2009. Plant-hummingbird interactions in the West Indies: Floral specialisation gradients associated with environment and hummingbird size. Oecologia 159(1):757-766. PMid:19132403. http://dx.doi.org/10.1007/s00442$008-1255-\mathrm{z}$

DALSGAARD, B., MARTÍN GONZÁLEZ, A.M., OLESEN, J.M., TIMMERMANN, A., ANDERSEN, L.H. \& OLLERTON, J. 2008. Pollination networks and functional specialization: a test using Lesser Antillean plant-hummingbird assemblages. Oikos 117(1):789-793. http:// dx.doi.org/10.1111/j.0030-1299.2008.16537.x
ENDRESS, P.K. 1994. Diversity and evolutionary biology of tropical flowers. Cambridge University Press, Cambridge.

FAEGRI, K. \& VAN DER PIJL, L. 1979. The principles of pollination ecology. Pergamon Press, London.

FAHRIG, L., BAUDRY, J., BROTONS, L., BUREL, F.G., CRIST, T.O., FULLER, R.J., SIRAMI, C., SIRIWARDENA, G.M. \& MARTIN, J.L. 2011. Functional landscape heterogeneity and animal biodiversity in agricultural landscapes. Ecol. Lett. 14(1):101-112. PMid:21087380. http://dx.doi.org/10.1111/j.1461-0248.2010.01559.x

FARIA R.R. \& ARAUJO A.C. 2010. Flowering phenology and pollination of ornithophilous species in two habitats of Serra da Bodoquena, Mato Grosso do Sul, Brazil. An. Acad. Bras. Cienc. 82(4):843-855. PMid:21152758. http://dx.doi.org/10.1590/S0001-37652010000400006

FEINSINGER, P. \& COLWELL, R.K. 1978. Community organization among neotropical nectar-feeding birds. Am. Zool. 18(4):779-795.

GRANTSAU, R. 1988. Os beija-flores do Brasil. Expressão e Cultura, Rio de Janeiro.

HADLEY, A.S. \& BETTS, M.G. 2009. Tropical deforestation alters hummingbird movement patterns. Biol. Lett. 5(1):207-210. PMid:19158031 PMCid:PMC2665823. http://dx.doi.org/10.1098/ rsbl.2008.0691

KLINK, C.A. \& MACHADO, R.B. 2005. A conservação do Cerrado brasileiro. Megadiversidade 1(1):147-155.

KÖPPEN, W. 1948. Climatologia. Fondo de Cultura Económica, México.

LARA, C. 2006. Temporal dynamics of flower use by hummingbirds in a highland temperate forest in Mexico. Ecoscience 13(1):23-29. http:// dx.doi.org/10.2980/1195-6860(2006)13[23:TDOFUB]2.0.CO;2

LUNAU, K., PAPIOREK, S., ELTZ, T. \& SAZIMA M. 2011. Avoidance of achromatic colors by bees provides a private niche for hummingbirds. $\mathrm{J}$ Exp Biol 214(1):1607-1612. PMid:21490268. http://dx.doi.org/10.1242/ jeb.052688

MACHADO, A.O. 2012. Diversidade de recursos florais para beija-flores nos cerrados do triângulo mineiro e região. Tese de doutorado, Universidade Federal de Uberlândia.

MACHADO, C.G. \& ROCCA, M.A. 2010. Protocolos para o estudo da polinização por aves. In Ornitologia e Conservação: Ciência Aplicada, Técnicas de Pesquisa e Levantamento (S.V. Matter, F.C. Straube, I. Accordi, V. Piacentini \& J.F. Cândido-Junor, eds). Technical Books, Rio de Janeiro, p.471-489.

MACHADO, C.G. 2009. Os beija-flores (Aves: Trochilidae) e seus recursos florais em área de caatinga da Chapada Diamantina, Bahia, Brasil. Rev. Bras. Zool. 26(2):255-265.

MACHADO, C.G.; COELHO A.G.; SANTANA C.S. \& RODRIGUES M. 2007. Beija-flores e seus recursos florais em uma área de campo rupestre da Chapada Diamantina, Bahia. Rev. Bras. Ornit. 15(2):267-279.

MACHADO, R.B., RAMOS NETO, M.B., PEREIRA, P.G.P., CALDAS, E.F., GONÇALVES, D.A., SANTOS, N.S., TABOR, K. \& STEININGER, M. 2004. Estimativas de perda da área do Cerrado brasileiro. Conservação Internacional, Brasília.

MARK, W.C., MICHAEL, F.F., JAMES, L.R., DOUGLAS, E.S., PAMELA, S.S., PETER, F., ARNE, A.A., MICHAEL, J.M., RICHARD, G.O., PAULA, J.R. \& KENNETH, J. 2009. An update of the Angiosperm Phylogeny Group classification for the orders and families of flowering plants: APG III. Bot. J. Linn. Soc. 161(2):105-121. http://dx.doi. org/10.1111/j.1095-8339.2009.00996.x

MARUYAMA, P.K. 2011. Disponibilidade de recursos florais e o seu uso por beija-flores em área de Cerrado de Uberlândia, MG. Dissertação de Mestrado, Universidade Federal de Uberlândia, Uberlândia.

MENDONÇA, L.B. \& ANJOS, L. 2005. Beija-flores (Aves, Trochilidae) e seus recursos florais em uma área urbana do Sul do Brasil. Rev. Bras. Zool. 22(1):51-59. http://dx.doi.org/10.1590/S0101-81752005000100007

METZGER, J.P., 2001. Effects of deforestation pattern and private nature reserves on the forest conservation in settlement areas of the Brazilian Amazon. Biota Neotrop. 1(1):1-14. http://dx.doi.org/10.1590/S167606032001000100003 
MITCHELL, R. J., IRWIN, R. E., FLANAGAN, R. J. \& KARRON, J.D. 2009. Ecology and evolution of plant-pollinator interactions. Ann. Bot. 103(1):1355-1363. PMid:19482881 PMCid:PMC2701755. http://dx.doi. org/10.1093/aob/mcp122

MYERS, N., MITTERMEIER, R.A., MITTERMEIER, C.G., FONSECA, G.A.B. \& KENT, J. 2000. Biodiversity hotspots for conservation priorities. Nature 403:853-858. PMid:10706275. http://dx.doi. org/10.1038/35002501

NICOLSON, S. \& THORNBURG, R.W. 2007. Nectar chemistry. In Nectary and Nectar: A Modern Treatise (S.W. Nicolson, M. Nepi \& Pacini E., eds). Springer-Varlig, Amsterdam, p.215-264. http://dx.doi.org/10.1007/9781-4020-5937-7_5

OLIVEIRA, M.I.B. \& SIGRIST, M.R. 2008. Fenologia reprodutiva, polinização e reprodução de Dipteryx alata Vogel (LeguminosaePapilionoideae) em Mato Grosso do Sul, Brasil. Revista Brasil. Bot. 31(2):195-207. http://dx.doi.org/10.1590/S0100-84042008000200002

OLIVEIRA, P.E. \& GIBBS, P.E. 2000. Reproductive biology of woody plants in a Cerrado community of central Brazil. Flora 195(4):311-329.
ORTIZ-PULIDO, R., DÍAZ, A., VALLE-DIÁZ, O.I. \& FISHER, A.D. 2012. Hummingbirds and the plants they visit in the Tehuacán-Cuicatlán Biosphere Reserve, México. Rev. Mex. Biodivers. 83(2):152-163.

PIACENTINI, V. \& VARASSIN, I.G. 2007. Interaction network and the relationships between bromeliads and hummingbirds in an area of secondary Atlantic rain forest in southern Brazil. J. Trop. Ecol. 23(1):663671.

ROCCA, M. A. \& SAZIMA, M. 2010. Beyond hummingbird-flowers: the other side of ornithophily in the neotropics. Oecologia Australis 14(1):6799. http://dx.doi.org/10.4257/oeco.2010.1401.03

RODRIGUES, L.C. \& ARAUJO, A.C. 2011. The hummingbird community and their floral resources in an urban forest remnant in Brazil. Braz. J. Biol. 71(3):611-622. PMid:21881784.

SAZIMA I., BUZATO, S. \& SAZIMA, M. 1995. The sawbilled hermit Ramphodon naevius and its flowers in southeastern Brazil. J. Ornithol. 136:195-206. http://dx.doi.org/10.1007/BF01651241

SULIKOWSKI, D. \& BURKE, D. 2010. When a place is not a place: encoding of spatial information is dependent on reward type. Behaviour 147(1):1461-1479. http://dx.doi.org/10.1163/000579510X521564 